\title{
UJI EFEKTIVITAS LARVASIDA EKSTRAK DAUN JAMBU BIJI TERHADAP LARVA AEDES AEGYPTI SP
}

\author{
Nesti Indrika Sitompul ${ }^{1}$ Riyani Susan BT Hasan ${ }^{2}$ \\ 1,2 Program Studi Pendidikan Dokter, Kedokteran Tropis, Fakultas Kedokteran, Universitas Prima Indonesia \\ nestisitompul@gmail.com
}

\begin{abstract}
Abstrak
Riset terhadap nyamuk larva aedes aegypti ini dilakukan guna mengetahui efektivitas daun jambu biji pada konsentrasi $2,5 \%, 5,0 \%, 7,5 \%$, dan $10,0 \%$ karena vector yang menyebabkan demam berdarah dengue (DBD) ialah nyamuk aedes aegypti. Penelitian ini menggunakan metode eksperimental dan the post test only controlled group design sebagai rancangannya, dengan metode purposive sampling sebagai teknik pengambilan sampel. Cara melakukan uji efektivitas ini adalah dengan cara memasukkan konsentrasi dari ekstrak daun jambu biji yang sudah ditentukan kedalam wadah yang telah berisi larva aedes aegypti. Kruskall-wallis dipilih sebagai metode pengolahan data yang dapat digunakan didalam uji coba penelitian ini, uji coba tersebut menunjukkan bahwa adanya perbedaan yang signifikan dengan indeks kepercayaan $95 \%$. Dimana dijumpai ekstrak daun jambu biji mulai memiliki efek larvasida pada jam ke-8 pada konsentrasi $10 \%$ dengan jumlah kematian larva 75\% dari 20 ekor larva dalam 1 wadah. Penelitian ini mendapatkan hasil yang sangat efektif dalam mematikan larva pada pengamatan selama 48 jam dengan konsentrasi $10 \%$ serta total kematian larva $100 \%$.
\end{abstract}

Kata Kunci : Ekstrak daun jambu biji dan Aedes Aegypti

\begin{abstract}
The study of Aedes aegypti larvae was conducted to evaluate guava leaf at concentrations of $2.5 \%, 5.0 \%, 7.5 \%$, and $10.0 \%$ because the vector that causes dengue hemorrhagic fever (DHF) is the Aedes aegypti mosquito. This study uses experimental and post test methods only to control the design of the group as a design, with the purposive sampling method as a sampling technique. The way to do this trial is by entering the contribution of the extract of guava leaf that have been determined in a container that has been filled with aedes aegypti larvae. Kruskall-walls was chosen as a data processing method that can be used in the trials of this study, this trial showed a significant significance with a confidence index of $95 \%$. Where it is found that guava leaf extracts begin to have larvicidal effects at the $8^{\text {th }}$ hour at a concentration of $10 \%$ with $75 \%$ larval mortality from 20 larvae in 1 container. This study found very effective results in killing larvae for 48 hours of monitoring with a concentration of $10 \%$ and $100 \%$ of larval mortality.
\end{abstract}

Keywords: Guava leaf extract and Aedes Aegypti 


\section{PENDAHULUAN}

Demam berdarah dengue (DBD) ialah penyakit menular yang disebabkan virus dengue dan disebarkan nyamuk yaitu spesies nyamuk aedes aegypti. Nyamuk yang menularkan dengue hampir ditemukan di seluruh Indonesia, kecuali di tempat yang memiliki ketinggian lebih dari 1000 meter di atas permukaan laut (1). Demam berdarah dengue yang disebabkan oleh virus dengue yang ditularkan oleh gigitan nyamuk Aedes aegypti. Penyakit ini ialah penyakit seperti demam akut disebabkan oleh serotipe virus dengue, ditandai dengan empat gejala klinis yaitu demam yang tinggi, manifestasi perdarahan, hepatomegali, dan tanda-tanda kegagalan sirkulasi sampai timbulnya renjatan (sindrom renjatan dengue) terjadinya akibat dari kebocoran plasma yang dapat menyebabkan kematian ${ }^{(2)}$

Data dari seluruh dunia mempublikasikan asia menduduki peringkat pertama dalam kasus penderita DBD setiap tahun. Menurut WHO, negara Indonesia merupakan negara dengan kasus penderita DBD yang paling tertinggi di Asia Tenggara dari tahun 1968 hingga 2009. ${ }^{(3)}$

Kasus DBD dipengaruhi dari jumlah penduduk pada suatu wilayah yang dicerminkan melalui perhitungan Incidence Rate (IR). Incidence Rate dari kota Blitar tahun 2016 adalah 189 per 100.000 orang. Nilai IR tersebut termasuk dalam klasifikasi sangat tinggi. (4)

Angka kesakitan DBD di tahun 2011 bagian wilayah provinsi Sulawesi utara khususnya daerah kota manado sebesar 156 kasus dari keseluruhan total 1485 kasus di wilayah provinsi sulut. Total kunjungan penderita DBD dari periode 2008-2012 di RSUP Prof. Dr. R. D Kandou manado mencapai 3077 dengan total keseluruhan kasus baru sebanyak 2736 dan dari analisa data instalasi rekam medik, jumlah penderita DBD yang menjalani masa rawat tahun 2013 di RSUP Prof. Dr. R. D Kandao manado dengan total 315 dan 242 diantaranya anak-anak dengan usia 2-12 tahun. ${ }^{(3)}$

Di beberapa titik wilayah, kasus DBD meningkat karena dipengaruhi curah hujan dan kelembapan udara. Maka dari beberapa kasus, puncak kejadian DBD terjadi pada puncak musim hujan. Dan karena itu, penanggulangan dibutuhkan rencana yang matang dalam mengendalikan penyebaran penyakit tersebut, khususnya di musim hujan. Pemaksimalan program penanggulangan DBD di beberapa dinas kesehatan dan puskesmas di daerah setempat. Cara tersebut menjadi kunci utama untuk penanggulangan penyebaran DBD itu sendiri. ${ }^{(5)}$
Kasus DBD di Indonesia berkembang pesat setiap tahunnya dan semakin meningkat angka kesakitannya sehingga sebaran wilayah yang terjangkit semakin luas. Penyakit ini tidak hanya sering menyebabkan KLB tetapi juga menyebabkan dampak buruk sosial maupun ekonomi. Kerugian sosial yang terjadi ialah karena menimbulkan kepanikan dalam keluarga, kematian anggota keluarga, dan berkurangnya usia harapan hidup. (6)

Gejala DBD yaitu demam dengan suhu $38 \mathrm{C}$ sampai 39 C. jika demam lebih dari 3 hari maka dilakukan uji torniket, pemeriksaaan igM, igG, igM dengue. Pemeriksaan igG biasannya dilakukan setelah melewati hari ke 3, dan pemeriksaan NS-1 dilakukan pada hari pertama atau ketiga tujuannya mengetahui mendeteksi virus dengue lebih cepat. Dan bisa juga dilakukan pemeriksaan cek darah rutin meliputi hemoglobin, hematokrit, leukosit, dan trombosit. Pengujian tersebut harus dilakukan untuk penderita sampai melewati masa fase kritis, yaitu fase yang terjadi setelah 5 hari untuk menjalani fase demam dan ialah merupakan fase yang paling rentan terjadi kelalaian sehingga menyebabkan keparahan bahkan sampai meninggal. (7)

Strategi pemberantasan Demam Berdarah Dengue lebih ditekankan pada upaya preventif, melaksanakan penyemprotan sebelum musim penularan penyakit di daerah endemis. Akibatnya strategi pemberantasan Demam Berdarah Dengue tidak terlaksana dengan baik sehingga setiap tahunnya Indonesia menimbulkan kejadian luar biasa (KLB) Demam Berdarah Dengue. ${ }^{(8)}$

Seharusnya masyarakat diberitahu pengetahuan dan ketrampilan tentang cara-cara pengendalian vektor untuk memilih pilihan terbaik yang berkaitan dengan masalah kesehatan secara individu maupun secara kolektif . Diharapkan dengan adanya kegiatan ini, masyarakat dapat lebih memperhatikan lingkungan agar dapat mencegah terjadinya penyebaran nyamuk demam berdarah di masa yang akan datang. Diharapkan juga lingkungan menjadi lebih hijau dan bersih (Eco Green). ${ }^{(9)}$

Ada beberapa faktor lingkungan rumah terjadi penyakit DBD ialah kepadatan rumah, terdapat perindukan nyamuk, tempat berkembang nyamuk, angka bebas jentik, dan lain - lain. ${ }^{(10)}$

Sampai saat ini vaksin untuk menanggulangi penyakit yang disebabkan oleh virus dengue ini belum ditemukan. Dalam Terapi antibiotik dapat diberikan pengobatan DBD jika didapati infeksi sekunder yang disebabkan adanya translokasi bakteri dari saluran cerna dan hal ini terjadi pada 
penderita DSS (Dengue Syok Syndrome) atau penderita DBD derajat III danIV. ${ }^{(3)}$

Penelitian ini bertujuan untuk mendapatkan hasil dari pengumpulan literatur mengenai perkembangan vaksin DBD dan meninjau berbagai potensi vaksin DBD berdasarkan sesuai dengan penelitian yang telah dilakukan di berbagai negara. ${ }^{(11)}$

\section{METODE}

Penelitian ini menggunakan the post test only controlled group design sebagai rancangannya. Rancangan ini digunakan karena sampel dipilih tanpa melakukan pretest terlebih dahulu. Peneliti melakukan pengambilan sampel dengan metode pusposive sampling

Lokasi dan Waktu

Laboratorium Kimia Organik Fakultas Matematika dan Ilmu Pengetahuan Alam Universitas Sumatera Utara dipilih sebagai tempat yang ideal untuk proses ekstraksi di bulan Agustus 2019. Kemudian melakukan pegujian ekstrak terhadap larva Aedes Aegypti Spp di Laboratorium Mikrobiologi Universitas Prima Indonesia pada bulan September 2019.

\section{Sampel Penelitian}

Sampel di penelitian ini ialah daun jambu biji (psidium guava) yang berasal dari pohon jambu biji di Labuhan batu, Rantau prapat. Larva nyamuk Aedes Aegypti dibeli dari Laboratorium Entomologi Institut Teknologi Bandung.

\section{Metode Pengumpulan Data}

Data dari ekstrak daun jambu biji (psidium guava) yang diambil selama penelitian berlangsung di laboratorium merupakan data primer dalam pengujian efektivitas terhadap larvasida nyamuk Aedes Aegypti.

\section{Instrumen Penelitian}

Perlengkapan yang dipakai dalam riset ini ialah Rotary evaporator, beaker glass, maserator, waterbath, Measuring cylinder, Stirring rod, kertas saring, pipet pasteur, botol ekstraksi, timbangan dan wadah / gelas.

Materi yang digunakan adalah daun jeruk nipis, larva Aedes Aegypti, etanol 96\%, dan aquadest.

\section{Prosedur Penelitian \\ Metode Ekstraksi}

Daun jambu biji yang diekstrak pada penelitian ini menggunakan metode maserasi. Pelarut yang dibutuhkan pada teknik maserasi ini ialah etanol 96\%. Daun jambu biji yang telah dikeringkan melalui lemari pengering sebanyak $3,5 \mathrm{Kg}$, lalu dilakukan proses penyerbukan daun yang sudah kering melalui media blender kemudian difilter menggunakan penyaring dan ditimbang dengan hasil $960 \mathrm{mg}$, proses selanjutnya maserasi lewat etanol $96 \%$ sejumlah $400 \mathrm{ml}$ dibaur serta didiamkan 72 jam suhu ruangan. Larutan difilter lalu rotary evaporator digunakan untuk menguapkan solvent. Jika ekstrak sudah didapat, kemudian diletakkan diatas waterbath hingga didapat ekstrak dengan konsistensi yang kental, kemudian dibagi kedalam 4 konsentrasi yaitu :

1. Konsentrasi daun jambu biji $2,5 \%$

Konsentrasi dari Ekstrak daun jambu biji 25\% diambil $10 \mathrm{ml}$ lalu dicampurkan ke dalam gelas yang berisi air $100 \mathrm{ml}$

2. Konsentrasi daun jambu biji 5,0\%

Konsentrasi dari Ekstrak daun jambu biji 50\% diambil $10 \mathrm{ml}$ lalu dicampurkan ke dalam gelas yang berisi air $100 \mathrm{ml}$

3. Konsentrasi daun jambu biji 7,5\%

Konsentrasi dari Ekstrak Daun jambu biji 75\% diambil $10 \mathrm{ml}$ lalu dicampurkan ke dalam gelas yang berisi air $100 \mathrm{ml}$

4. Konsentrasi Daun jambu biji $10 \%$ :Konsentrasi dari Ekstrak Daun jambu biji 100\% diambil 10ml lalu dicampurkan ke dalam gelas yang berisi air $100 \mathrm{ml}$

\section{Inkubasi Telur Nyamuk Aedes Aegypti}

Laboratorium Mikrobiologi Universitas Prima Indonesia dipilih sebagai tempat inkubasi telur nyamuk Aedes Aegypti. Larva Aedes Aegypti yang diperoleh melalui proses inkubasi dipergunakan untuk sampel pada riset ini.

1. Kertas yang berisi telur kemudian dipotong sesuai kebutuhan lalu di letakkan di wadah tempat penetasan

2. Wadah diisi air yang sudah di endapkan selama satu malam

3. Pastikan kertas terendam air

4. Taruh pakan ikan yang sudah dihaluskan kedalam wadah

5. Tunggu hingga 3 hari telur nyamuk Aedes Aegypti akan menetas

Langkah - langkah Penelitian

1. Mempersiapkan 5 gelas air dan diisi 20 larva dalam setiap gelas

2. Menyiapkan gelas yang sudah dimasukkan ekstrak daun jambu biji dengan memberi tanda konsentrasi Kontrol, 2,5\%, 5,0\%, 7,5\%, dan $10 \%$.

3. Mengamati dalam rentang waktu 30 menit, serta dilanjutkan dengan waktu $1,2,4,8,12$, 24, dan terakhir 48 jam.

4. Percobaan dilakukan selama tiga kali pengulangan 
Jurnal Ilmiah Mahasiswa Kesehatan Masyarakat Vol. 5/No. 3/ Juli 2020; Issn: 2502-731X

\section{Analisis data}

Setelah didapatkan data kematian dari total larva Aedes aegypti, kemudian dilakukan olah data menggunakan uji Kruskall-Wallis lewat SPSS software.

HASIL

Riset ini dilaksanakan di laboratorium Mikrobiologi Universitas Prima Indonesia pada tanggal 12 hingga 20 September 2019. Dengan memanfaatkan ekstrak daun dari jambu biji ( psidium guava)

sebagai sampel kepada larva Aedes Aegypti. Berdasarkan observasi selama 48 jam dijumpai kematian pada larva Aedes Aegypti dilihat pada gambar di bawah ini:

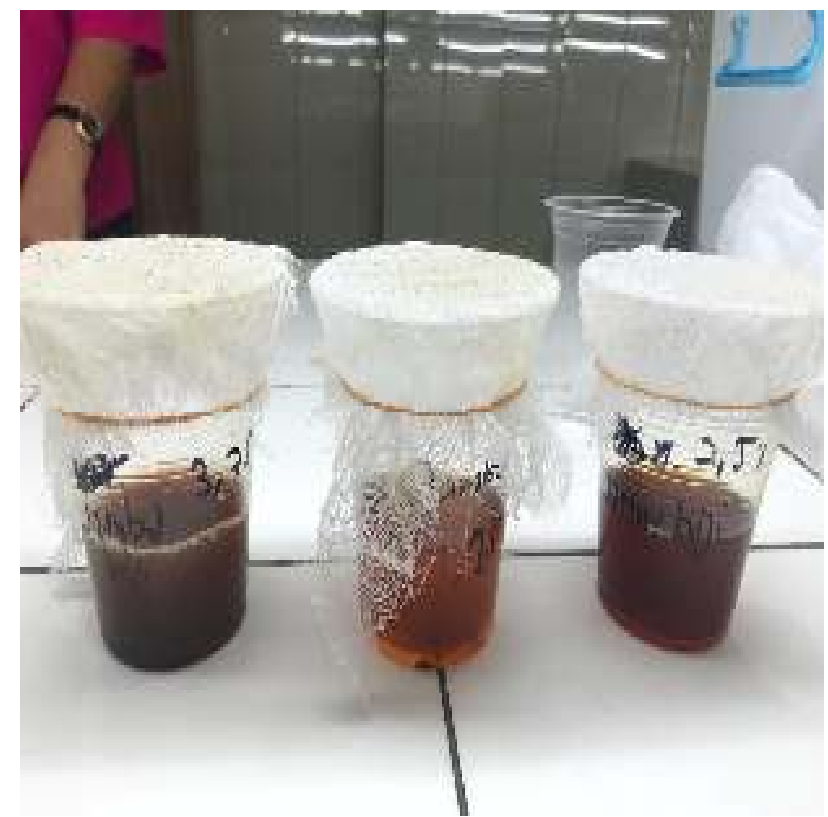

Gambar 1 ditemukan larva Aedes Aegypti yang mati dalam wadah ekstrak berisi daun jambu biji (psidium guava ) dalam beberapa konsentrasi

Tabel 1. Hasil Pengamatan larva Aedes Aegypti yang diberi ekstrak daun jambui biji dalam konsentrasi $\mathbf{2 , 5 \%}$ dan $\mathbf{5 , 0} \%$

\begin{tabular}{lcccccc}
\hline Waktu & \multicolumn{3}{c}{$2,5 \%$} & & \multicolumn{3}{c}{$5,0 \%$} \\
& I & II & III & I & II & III \\
\hline 30 menit & 0 & 0 & 0 & 0 & 0 & 0 \\
\hline 1 jam & 0 & 0 & 0 & 0 & 0 & 0 \\
\hline 2 jam & 0 & 0 & 0 & 1 & 0 & 0 \\
\hline 4 jam & 1 & 1 & 1 & 3 & 1 & 1 \\
\hline 8 jam & 1 & 2 & 2 & 4 & 7 & 2 \\
\hline 12 jam & 2 & 1 & 2 & 6 & 3 & 2 \\
\hline
\end{tabular}

Tabel 2. Hasil Pengamatan larva Aedes Aegypti yang diberi ekstrak daun jambu biji dalam Konsentrasi 7,5\% dan

\begin{tabular}{cccccccc}
\hline & \multicolumn{3}{c}{$\begin{array}{c}7,5 \% \\
\text { Waktu }\end{array}$} & I & II & & \multicolumn{3}{c}{$10,0 \%$} & I & II & III \\
\hline 30 menit & 0 & 0 & 0 & 0 & 0 & 0 \\
\hline 1 jam & 0 & 0 & 0 & 0 & 0 & 0 \\
\hline 2 jam & 2 & 0 & 0 & 2 & 1 & 0 \\
\hline 4 jam & 3 & 1 & 3 & 4 & 3 & 3 \\
\hline 8 jam & 2 & 11 & 2 & 7 & 8 & 5 \\
\hline 24jam & 7 & 5 & 1 & 3 & 2 & 10 \\
\hline
\end{tabular}

Tabel 1 \& 2 menunjukkan hasil observasi selama 48, dengan pengulangan sebanyak tiga kali yang ditulis dalam persentase. Tidak ditemukannya kematian pada kelompok kontrol larva Aedes Aegypti di ketiga pengulangan tersebut. efektivitas ekstrak mulai terlihat pada 8 jam pertama di konsentrasi $2,5 \%$, sedangkan dalam konsentrasi 5,0\%, 7,5\% serta $10,0 \%$ terlihat pada jam ke 4 observasi, akan tetapi untuk kematian seluruh populasi larva Aedes aegypti yang membutuhkan 24 jam sampai 48 jam Hubungan mula kerja ekstrak daun jambu biji (Psidium Guava) terhadap larva Aedes aegypti dapat diperhatikan pada diagram dibawah ini :

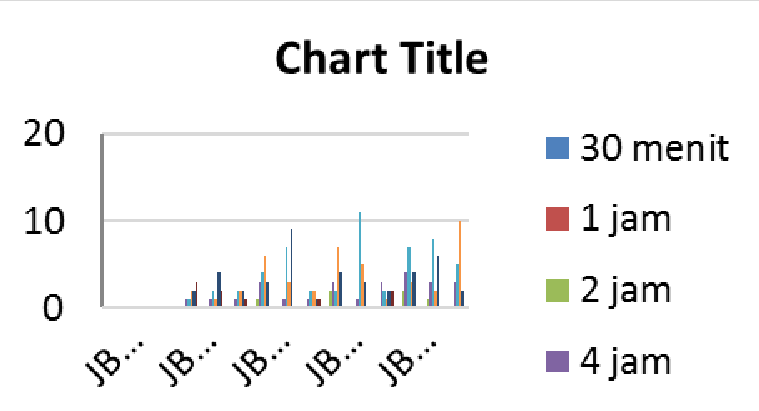

Gambar 2. Hubungan lama pemberian ekstrak daun jambu biji terhadap larva Aedes Aegypti

\section{DISKUSI}

Berdasarkan hasil riset ini diperoleh manfaat dari ekstrak daun jambu biji ( psidium guava) yaitu adanya efektivitas daun jambu biji ( psidium guava). Data hasil penelitian ini diberikan dalam bentuk persen jumlah larva yang mati setiap satuan waktu observasi. Persen larva yang mati tersebut kemudian dianalisa secara analistik non-parametrik karena jumlah sampel yang minim. Uji Kruskal-wallis digunakan sebagai analisa statistik dalam penelitian ini. Mengenai hasil analisa berikut ditunjukan pada tabel di bawah ini 
Tabel 3. Perbandingan Persen Larva yang Mati pada Masing-Masing Kelompok Sampel

\begin{tabular}{|c|c|c|c|c|c|}
\hline \multirow{3}{*}{ Waktu } & \multicolumn{4}{|c|}{ Persen larva mati [Median (Range) ] } & \multirow{3}{*}{ Nilai P } \\
\hline & \multicolumn{4}{|c|}{ Ekstrak Daun Jambu biji } & \\
\hline & $2,5 \%$ & $5,0 \%$ & $7,5 \%$ & $10,0 \%$ & \\
\hline 30 menit & 0 & 0 & 0 & 0 & 1,000 \\
\hline 1 jam & 0 & 0 & 0 & 0 & 1,000 \\
\hline 2 jam & 0 & 1 & 2 & 3 & 0,345 \\
\hline 4 jam & 3 & 5 & 7 & 10 & 0,022 \\
\hline 8 jam & 5 & 13 & 15 & 20 & 0,034 \\
\hline 12 jam & 5 & 11 & 13 & 13 & 0,065 \\
\hline 24 jam & 8 & 13 & 9 & 12 & 0,113 \\
\hline 48 jam & 6 & 1 & 2 & 0 & 0,066 \\
\hline
\end{tabular}

Dari data tabel 3 dapat dilihat bahwa perbedaan persen larva yang mati dari masingmasing terlihat jelas pada pengamatan setelah 8 jam pemberian ekstrak kepada larva nyamuk Aedes aegypti. Keadaan ini tampak dari perbandingan nilai p yang mempunyai hasil $<0.05$ adalah pengamatan setelah 8 jam.

Sebagai analisa lebih lanjut kemudian ditentukan rata periode waktu yang paling cepat yang dibutuhkan dari masing-masing ekstrak daun jambu biji guna mematikan larva nyamuk Aedes aegypti. Proses analisa ini memiliki hasil pada tabel dibawah ini :

Tabel 4. Perbandingan Periode Minimal Bunuh Larva pada Ekstak Daun Jambu Biji

\begin{tabular}{|c|c|c|}
\hline $\begin{array}{l}\text { Konsentrasi } \\
\text { ekstrak daun } \\
\text { jambu biji }\end{array}$ & $\begin{array}{l}\text { Periode Minimal } \\
\text { Bunuh Larva ( jam ) } \\
\text { [median (range)] }\end{array}$ & $\begin{array}{c}\text { Nilai } \\
\text { P }\end{array}$ \\
\hline $2,5 \%$ & $4(3)$ & \multirow{4}{*}{0,392} \\
\hline $5,0 \%$ & $4(3)$ & \\
\hline $7,5 \%$ & $4(3)$ & \\
\hline $10,0 \%$ & $2(1)$ & \\
\hline
\end{tabular}

Dari data tabel 4 menunjukkan jika tidak memiliki perbedaan seacara statistik bermakna dalam waktu minimal yang dibutuhkan oleh masingmasing konsentrasi sampel guna mematikan larva nyamuk aedes aegypti. Hal tersebut terlihat lewat hasil analisa kruskal-wallis dimana memperlihatkan nilai $P>0.05$. Meskipun pada nilai median dan range dari konsentrasi $2.5 \%$ sampai $7.5 \%$ berbeda dengan konsentrasi $10.0 \%$ namun secara stastistik perbedaan itu tidak menunjukkan kemaknaan, dengan besarnya nilai range pada konsentrasi $10.0 \%$ menjukkan bahwa persebaran yang lebar pada periode minimal yang dibutuhkan guna mematikan larva nyamuk Aedes aegypti dibandingkan dengan kosentrasi lainnya.

Kemudian untuk mengetahui seberapa efektifnya ekstrak dari daun jambu biji guna mematikan larva nyamuk Aedes aegypti maka dilakukan penentuan nilai LD50 dari ekstrak daun jambu biji guna membunuh larva nyamuk Aedes aegypti setelah 4 jam observasi. Untuk menentukan nilai LD50 tersebut terlebih dahulu dilakukan analisa regresi linear. Hasil analisa berikut ditampilkan di tabel ini.

Tabel 5. Analisa Regresi Linear pada Persen Larva Mati Setelah 4 Jam Observasi

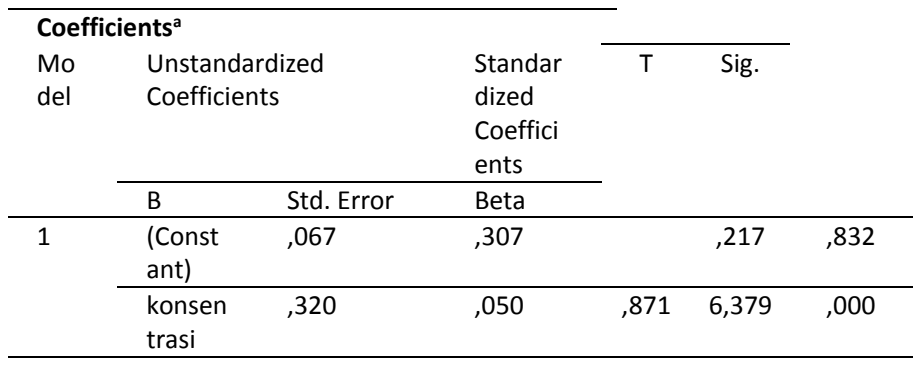

$\mathrm{R} 2=0.578$

Sehingga, dari hasil analisa regressi linear tersebut dapat dilihat bahwa persamaan yang didapat adalah sebagai berikut:

$\mathrm{Y}=0,067+0,320 \mathrm{X}+\mathrm{e}$

Dengan persen larva yang mati (\%) adalah $\mathrm{Y}$ dan konsentrasi ekstrak daun jambu biji (\%) adalah $\mathrm{x}$. Sementara nilai $\mathrm{R}^{2}$ dari persamaan berikut adalah 0,758 yang artinya persamaan tersebut dapat memprediksi nilai larva yang mati sebesar $75,8 \%$. Dengan menggunakan persamaan tersebut dapat dihitung nilai LD50 dari ekstrak daun jambu biji setelah 4 jam pengamatan adalah sebesar 54,67\%. Hal ini mengatakan jika dibutuhkan konsentrasi ekstrak yang lebih tinggi yaitu $54,67 \%$ ekstrak daun jambu biji untuk dapat membunuh setengah dari larva yang ada setelah 4 jam pemberian ekstrak. Pada hasil penelitian uji efektivitas ekstrak dari daun jambu biji ( psidium guava) terhadap larva Aedes Aegypti menunjukkan adanya pengaruh secara statistic bermakna persen larva yang mati. Hal ini tercermin dari nilai $\mathrm{P}<0,05$ pada observasi 4 jam pertama pemberian ekstrak pada larva Aedes Aegypti dan kematian total pada 48 jam observasi.

Hasil riset ini sesuai dengan penelitian Murdani ( 2014 ) yang melakukan observasi selama 24 jam dengan konsentrasi ekstrak 0,1\%, 0,2\%, 
0,3\%, 0,4\% dan 0,5\% Dan pada penelitian ini juga dilakukan penghitungan LD50 yang tidak dihitung pada penelitian sebelumnya

\section{SIMPULAN}

1. Bahwa terdapat adanya pengaruh larvasida ekstrak dari daun jambu biji ( psidium guava) terhadap kematian larva Aedes Aegypti $(\mathrm{PI}=0,018)$.

2. Efektivitas ekstrak dari daun jambu biji (psidium guava) untuk membunuh larva Aedes Aegypti pada konsentrasi 2,5\% membunuh sebanyak $10 \%$ larva, 5,0\% terjadi kematian sebanyak $80 \%$, konsentrasi $7,5 \%$ membunuh sebanyak $20 \%$ larva dan pada konsentrasi $10,0 \%$ membunuh sebanyak $75 \%$ larva.

3. Penelitian ini memiliki hasil yang sangat efektif guna mematikan larva pada pengamatan selama 48 jam ialah konsentrasi $10 \%$ dengan total kematian larva $100 \%$

4. Nilai LD50 terhadap larva Aedes Aegypti yang efektif membunuh dalam 4 jam pertama observasi adalah konsentrasi $54,67 \%$.

\section{SARAN}

1. Dapat menggunakan ekstrak daun jambu biji yang bersifat ramah lingkungan karena merupakan produk herbal sebagai alternative pengganti abate yang berasal dari bahan kimia untuk mencegah penyebaran penyakit DBD.

2. Untuk Instansi pemerintah terutama dinas kesehatan untuk sosialisasi ke daerah - daerah dengan kasus DBD tinggi bagaimana cara pembuatan dan penggunaan ekstrak daun jambu biji sebagai alternative penggunaan bahan kimia yaitu abate.

3. Perlu dilakukan penelitian lebih spesifik tentang kandungan daun jambu biji ( psidium guava)

\section{DAFTAR PUSTAKA}

1. Rahayu, Y., Stia Budi, I. and Yeni (2017) 'Analisis Partisipasi Kader Jumantik Dalam Upaya Penanggulangan Demam Berdarah Dengue (Dbd) Di Wilayah Kerja Puskesmas Indralaya', Jurnal IImu Kesehatan Masyarakat. doi: 10.26553/jikm.2017.8.3.200-207.

2. Prasetyani, R. D. (2015) 'Faktor-Faktor Yang Berhubungan Dengan Kejadian Demam Berdarah Dengue', journal Majority, 4(7), pp. 61-66. Available at: https://juke.kedokteran.unila.ac.id

3. Andriani, N. W. E., Tjitrosantoso, H. and
Yamlean, P. V. Y. (2014) 'Kajian Penatalaksanaan Terapi Pengobatan Demam Berdarah Dengue (DBD) Pada Penderita Anak Yang Menjalani Perawatan Di RSUP Prof. DR. R. D Kandou Tahun 2013', Jurnal Ilmiah Farmasi.

4. Kasus, G. et al. (2018) 'The Overview of Dengue Hemorrhagic Fever Cases in Blitar City from 2015 to 2017', Jurnal Berkala Epidemiologi, 6, pp. 260-267. doi: 10.20473/jbe.v6i3.2018.260-267.

5. Jacob and Sandjaya (2018) 'Jurnal Nasional IImu Kesehatan ( Jnik )', Faktor Faktor Yang Mempengaruhi Kualitas Hidup Masyarakat Karubaga District Sub District Tolikara Propinsi Papua.

6. Ishak, I. (2018) 'Studi Kualitatif Perilaku Pencegahan Deman Berdarah pada Rumah Tangga', Journal of Health Studies, 2(1), pp. 12-23. doi: 10.31101/jhes.430.

7. Novitasari, F. P. et al. (2019) 'Manajemen Discharge Planning pada Klien dengan Demam Berdarah Dengue (DBD)', Jurnal Kesehatan. doi: $10.26630 / j k . v 10 i 2.1330$.

8. Steva Tairas, G. D . Kandou, J. P. (2015) 'Analisis Pelaksanaan Pengendalian Demam Berdarah Dengue di Kabupaten Minahasa Utara', Jikmu, 5(1), pp. 21-29.

9. Setiyawan, H. et al. (2019) 'Penyuluhan Demam Berdarah Dengue (Dbd) Dan Tanaman Pengusir Nyamuk Di Desa Modalan, Banguntapan', Jurnal Pemberdayaan: Publikasi Hasil Pengabdian Kepada Masyarakat, 3(2), p. 241. doi: 10.12928/jp.v3i2.849.

10. Marwanty, M. and Miko Wahyono, T. Y. (2019) 'Faktor Lingkungan Rumah dan Kejadian Demam Berdarah Dengue di Kota Palopo 2016', Jurnal Epidemiologi Kesehatan Indonesia, 2(1), pp. 19-26. doi: 10.7454/epidkes.v2i1.3106.

11. Herdady, M. R. and Mustarichie, R. (2018) 'Artikel Review: Perkembangan dan Potensi Vaksin DBD Dari Berbagai Negara', Farmaka, 16(3), pp. 106-115. 